\title{
Effect of Volatile Toxins of Brassica Residues on Groundnut Stem and Pod Rot Disease caused by $S$. rolfsii
}

\author{
T. Yella Goud ${ }^{1 *}$, G. Uma Devi ${ }^{1}$, P. Narayan Reddy ${ }^{1}$ and A. Siva Sankar ${ }^{2}$ \\ ${ }^{1}$ Department of Plant Pathology, College of Agriculture, Acharya N G Ranga Agricultural \\ University, Rajendranagar, Hyderabad500 030, Andhra Pradesh, India \\ ${ }^{2}$ Department of Plant Physiology, College of Agriculture, Acharya N G Ranga Agricultural \\ University, Rajendranagar, Hyderabad500 030, Andhra Pradesh, India \\ *Corresponding author
}

\begin{tabular}{|c|c|}
\hline \multicolumn{2}{|r|}{ A B S T R A C T } \\
\hline & \multirow{5}{*}{$\begin{array}{l}\text { Stem and pod rot of groundnut caused by the pathogen Sclerotium rolfsii, which has a } \\
\text { wide host range and it affects the yield losses up to } 30-40 \% \text { in groundnut in India. The } \\
\text { persistence of infection caused by sclerotia of } S \text {. rolfsii inciting disease stem and pod rot of } \\
\text { groundnut following the incorporation of mustard (Brassica nigra) plant parts into soil was } \\
\text { examined through an experiment under greenhouse conditions. Incorporation of the } \\
\text { mustard plant parts into the soil reduced the infectivity of } S \text {. rolfsii at every date at which } \\
\text { inoculum was added to soil over the } 13 \text { day period of assessment. The effect of adding the } \\
\text { mustard plant parts significantly reduced the disease incidence of } S \text {. rolfsii. Initially the } \\
\text { disease incidence was minimum ( } 37.33 \% \text { ) at } 0 \text { day application of } S \text {. rolfsii immediately } \\
\text { after incorporation of mustard plant parts. Thereafter the disease incidence increased from } \\
1^{\text {st }} \text { day of application of pathogen to } 5^{\text {th }} \text { day ( } 46.66 \%, 54.00 \% \text { and } 65.33 \% \text { ), respectively. } \\
\text { Later from } 7^{\text {th }} \text { day onwards the disease incidence reduced from } 63.66 \% \text { to } 52.33 \% \text { up to } \\
\text { the } 13^{\text {th }} \text { day. }\end{array}$} \\
\hline Keywords & \\
\hline $\begin{array}{l}\text { S. rolfsii, mustard, } \\
\text { glucosinolates, } \\
\text { isothiocynates, and } \\
\text { groundnut }\end{array}$ & \\
\hline Article Info & \\
\hline & \\
\hline
\end{tabular}

\section{Introduction}

Brassica-cover crops are increasingly used as catch crops and/ or green manure crops with in rotations to provide a number of agronomic benefits like control of nitrogen leaching, increased soil organic matter and improved soil structure. They also have the potential to suppress a range of soil borne crop pests and diseases (Muechlchen et al., 1990; Snapp et al., 2007). Brassica species contain glucosinolates (GSL), which, upon tissue disruption, are hydrolyzed in the presence of water by an endogenous myrosinase enzyme into numerous compounds, notably toxic isothiocynates (ITC). The detrimental effect of pure ITC to certain fungi has long been known and the potential of Brassica crops to control soil borne pests and pathogens mainly attributed to these compounds. This process termed as "bio-fumigation" (Angus et al., 1994), is increasing interest as it is viewed as an alternative to the use of traditional inorganic soil fumigants in the control of soil pathogens. Brown and Morra (Brown et al., 1997) reviewed the factors contributing to biofumigation efficacy (efficiency of ITC release, susceptibility of the target species, 
soil moisture content, etc.) and suggested that, as the life time of GSL products in the environment was shown to be short (Brown et al., 1997; Morra and Kirkegard, 2002) "a short residue time places limits on achieving effective control and may contribute to the variability observed in the suppression of soilborne plant pathogens.

Groundnut (Arachis hypogea L.) is cultivated around the world in tropical, sub-tropical and warm temperate climates. The total area under groundnut in India is $6.70 \mathrm{~m}$. ha annually with a total production of 7.16 million tones. Andhra Pradesh ranks first with an area of $1.76 \mathrm{~m}$. ha and annual production of 0.95 million tones. Losses due to seed and seedling diseases particularly stem and pod rot of groundnut caused by $S$. rolfsii have been reported to an extent of 30-50 per cent in individual plots (Pande and Rao 2000).The aim of this study was to determine the persistence of action of $B$. nigra residues in the soil for the disease control. This was achieved by linking the time at which inoculum was introduced into the soil following the incorporation of $B$. nigra residues to the disease expression of stem rot of groundnut.

\section{Materials and Methods}

\section{Cultivation of mustard plants}

The locally available mustard (Brassica juncea) was used for green house experiment. Single mustard plant was raised for each pot. Each earthen pot of $27 \mathrm{~cm}$ height and $13 \mathrm{~cm}$ radius was filled with $4 \mathrm{~kg}$ of potting mixer consisting three parts of red soil and one part of black soil and sufficient amount of urea, single super phosphate (SSP), murate of potash (MOP), farm yard manure (FYM) and vermicompost. The experiment was maintained in completely randomized design with three replications per each treatment.

\section{Preparation of mustard green manure}

Sixty day old mustard plants were harvested along with the stem, leaves, flowers, and roots, chopped into small pieces and incorporated into the soil immediately to a depth of $15 \mathrm{~cm}$ from the top of the pot [8]. A little quantity of water was added to hydrolyse the glucosinolates and covered with polythene sheet for 15 days. The quantity of mustard plant parts incorporated into the soil is equivalent to $200 \mathrm{~g}$ fresh weight per pot. Control pots were maintained without mustard incorporation.

\section{Soil infestation}

According to the literature, the life of ITC and GSL in soil was shown to 6 and 8 days, respectively, at the most (Rahmanpour et al., 2009). As the purpose of this study was to determine the time when the effect of ITC would shut down, it was decided to work on a fine time scale of 13 days. The fungal propagules were incorporated into the soil at different times $(0,1,3,5,7,9,11$ and 13 days) after the incorporation of mustard plant parts. At each time, ten sclerotia of the fungus $S$. rolfsii were placed into the soil at a depth of $1 \mathrm{~cm}$ from the top of the soil.

Eight treatments and five replications were maintained in a completely randomized block design (Table I). Fifteen days after incorporation of mustard residues a seed of groundnut was sown $1 \mathrm{~cm}$ away from the sclerotial bodies. Fertilizers were not applied before and after 15 days of incorporation of mustard plant parts in the pots. The infectivity of $S$. rolfsii was estimated based on the number of groundnut plants infected. The seedlings were examined visually, for the presence of dark-brown lesions and white mycelia growth and the disease incidence was calculated by using the following formula as described by Mayee and Datar (1986). 


\section{Results and Discussion}

The experiment was conducted in glass house, Department of Plant Pathology, College of Agriculture, Rajendranagar, Hyderabad under artificially inoculated conditions to evaluate the persistence of mustard crop residues in the soil in reducing infection caused by sclerotia of $S$. rolfsii and the results are presented in table II.

The incorporation of the mustard plant parts into the soil reduced the infectivity of $S$. rolfsii at every date at which inoculum was added to soil over the 13 day period of assessment. The effect of adding the mustard plant parts significantly reduced the disease incidence of $S$. rolfsii. Initially the disease incidence was minimum (37.33\%) at 0 day application of $S$. rolfsii immediately after incorporation of mustard plant parts.

Thereafter the disease incidence increased from $1^{\text {st }}$ day of application of pathogen to $5^{\text {th }}$ day $(46.66 \%, 54 \%, 65.33 \%)$ respectively. Later from $7^{\text {th }}$ day onwards the disease incidence was reduced from $63.66 \%$ to $52.33 \%$ up to the $13^{\text {th }}$ day.

Table.1 The treatments and combinations

\begin{tabular}{|l|l|}
\hline S. No & Treatments \\
\hline 1 & $\mathrm{~T}_{1}-$ Pathogen application on the same day of mustard incorporation $(0$ day) \\
\hline 2 & $\mathrm{~T}_{2}-$ Pathogen application on $1^{\text {st }}$ day after mustard incorporation \\
\hline 3 & $\mathrm{~T}_{3}$-Pathogen application on $3^{\text {rd }}$ day after mustard incorporation \\
\hline 4 & $\mathrm{~T}_{4}-$ Pathogen application on $5^{\text {th }}$ day after mustard incorporation \\
\hline 5 & $\mathrm{~T}_{5}$-Pathogen application on $7^{\text {th }}$ day after mustard incorporation \\
\hline 6 & $\mathrm{~T}_{6}-$ Pathogen application on $9^{\text {th }}$ day after mustard incorporation \\
\hline 7 & $\mathrm{~T}_{7}-$ Pathogen application on $11^{\text {th }}$ day after mustard incorporation \\
\hline 8 & $\mathrm{~T}_{8}$-Pathogen application on $13^{\text {th }}$ day after mustard incorporation \\
\hline
\end{tabular}

Table.2 Effect of volatile compounds of Brassica residues at different dates of soil infestation of S. rolfsii under green house

\begin{tabular}{|l|c|c|}
\hline Treatment & Plant height(cm) & PDI \\
\hline $\begin{array}{l}\mathrm{T}_{1} \text { - Pathogen application on the same day of mustard } \\
\text { incorporation (0 day) }\end{array}$ & 22.00 & $37.33(37.64)^{*}$ \\
\hline $\mathrm{T}_{2}$ - Pathogen application on $1^{\text {st }}$ day after mustard incorporation & 19.16 & $46.66(43.07)$ \\
\hline $\mathrm{T}_{3}$ - Pathogen application on $3^{\text {rd }}$ day after mustard incorporation & 18.33 & $54.00(47.28)$ \\
\hline $\mathrm{T}_{4}$ - Pathogen application on $5^{\text {th }}$ day after mustard incorporation & 15.50 & $65.33(53.91)$ \\
\hline $\mathrm{T}_{5}$ - Pathogen application on $7^{\text {th }}$ day after mustard incorporation & 15.76 & $63.66(52.92)$ \\
\hline $\mathrm{T}_{6}$ - Pathogen application on $9^{\text {th }}$ day after mustard incorporation & 16.00 & $60.33(50.94)$ \\
\hline $\begin{array}{l}\mathrm{T}_{7} \text { - Pathogen application on } 11^{\text {th }} \text { day after mustard } \\
\text { incorporation }\end{array}$ & 16.66 & $57.33(49.20)$ \\
\hline $\begin{array}{l}\mathrm{T}_{8} \text { - Pathogen application on } 13^{\text {th }} \text { day after mustard } \\
\text { incorporation }\end{array}$ & 22.33 & $52.33(46.32)$ \\
\hline S. Em \pm & 1.41 & $1.74(1.01)$ \\
\hline CD at 5\% & 4.27 & $5.28(3.07)$ \\
\hline
\end{tabular}

*Figures in the parentheses indicate angular transformed value 
Similar trend was observed with regard to plant height of groundnut when brassica plant parts were incorporated into the soil. The plant height was reduced from 0 day to $5^{\text {th }}$ day $(22 \mathrm{~cm}$ to $15.5 \mathrm{~cm})$ and from $7^{\text {th }}$ day there was increase in plant height of groundnut from 15.76 to $22.33 \mathrm{~cm}$ though not much variation was found. It was also observed that in the inoculated control the groundnut did not germinate until $3^{\text {rd }}$ day of application. From $5^{\text {th }}$ day onwards groundnut seeds germinated though with poor vigour and the height of the plant was only $5 \mathrm{~cm}$ and later the plants wilted. Results of Motisi et al., (2009) also indicated that incorporation of above ground parts alone (AP) or the above-ground parts combined with the below ground parts $(\mathrm{AP}+\mathrm{BP})$ reduced the infectivity of inoculums of both Rhizoctonia solani and Gaeumannomyces graminis var. graminis tritici at every date at which inoculums was added to soil over the 13-day period of assessment. However, the persistence of ITC in soil after the grinding and incorporation of Brassica residues was shown to be short and according to previous studies, no longer than 3 days has been reported by Gardiner et al.,(Gardiner et al., 1999), Morra and Kirkegaard (2002) to 6 days (Gimsing and Kirkegaard, 2006). In the present investigation the mustard plant parts were mixed with the soil in all the pots at a time and the pathogen $S$. rolfsii was added from 0 day onwards until the $13^{\text {th }}$ day. Later the groundnut seeds were sown $1 \mathrm{~cm}$ away from $S$. rolfsii on the 15 day at a time in all the pots. It is clearly seen that by the time the mustard plant parts started producing the volatiles the sclerotia of $S$. rolfsii also took time to germinate and proliferate in the soil from 0 to 5 days. But the mustard volatiles did have an effect on germination of groundnut and the plant height. In spite of the pathogen the groundnut seed could germinate and recorded a significant plant height. From the $7^{\text {th }}$ day the pathogen was suppressed and the groundnut plant height also increased. Present investigation also showed that the persistence of brassica residues was significantly shorter than the persistence of residue action. However these results provide valuable insight into the relative efficacy of control afforded by the brassica residues considering the small amount of material added and the toxin released into the soil and the suppressive capacity of the residues is remarkable. On contrary, a recent study of Mazzola et al., (2007) demonstrated that the suppression of $R$. solani AG-5 by Brassica juncea seed meal amendments was associated with the release of allylisothiocynate in the first day. This supports the present results on the temporal changes in the efficacy of disease control by $B$. juncea residues. The following explanation for the trends observed in the present experimentation is proposed that the describing changes in the control of $S$. rolfsii over time for mustard residues were the result of an initial decrease in efficacy (during the first 5 days) resulting from the fast disappearance of the toxins released by the residues.

\section{References}

Angus, J.F., Gardner, P.A., Kirkegaard, J.A and Desmarchelier, J.M. 1994. Biofumigation: Isothiocynates released from Brassica roots inhibit growth of the take-all fungus. Plant and Soil. 162: 107-112.

Brown, P.D. and Morra, M.J. 1997. Control of soil-borne plant pests using glucosinolate-containing plants. Advances in Agronomy. 61: 167-231.

Brown, P.D., Morra, M.J., Mc Caffrey, J.P., Auld, D.L and Williams. 1991. Allelochemicals produced during glucosinolates degradation in soil. Journal of chemistry and Ecology. 17: 2021-2034.

Gardiner, J.B., Morra, M.J., Eberlein, C.V., 
Brown, P.D and Borek, V. 1999. Allelochemical released in soil following incorporation of rapeseed (Brassica napus) green-manures. Journal of Agriculture and food chemistry. 47: 3837-3842.

Gimsing, A.L and Kirkegaard, J.A. 2006. Glucosinolate and isothiocynate concentration in soil following incoprporation of Brassica biofumigants. Soil Biology and Biochemistry. 38: 2255-64.

Mayee, C.D and Datar, V. 1986. Phytopathometry. Marathwada Agricultural University Tech, Parbhani. 56.

Mazzola, M., Brown, J., Izzo, A.D and Cohen, M.F. 2007. Mechanism of action and efficacy of seed mealinduced pathogen suppression differ in a Brassicaceae species and time dependent manner. Phytopathology. 97: 454-460.

Morra, M.J and Kirkegard, J.A. 2002. Isothiocyanate release from soilincorporated Brassica tissues. Soil Biology \& Biochemistry. 34: 1683-90.

Motisi, N., Montfort, F., Dore, T., Romillac,
$\mathrm{N}$ and Lucas, P. 2009. Duration of control of two soil borne pathogens following incorporation of above and below-ground residues of Brassica juncea into soil. Plant Pathology. 58: 470-478.

Muechlchen, A.M., Rand, R.E and Parke, J.L. 1990. Evaluation of crucifer green manures for controlling Aphanomyces root rot of peas. Plant Disease. 74: 651654.

Pande, S., and Rao, J.N. 2000. Changing scenario of groundnut diseases in Andhra Pradesh, Karnataka and Tamil $\mathrm{Nadu}$ states of India. International Arachis Newsletter. 20: 42-44.

Rahmanpour, S., Backhouse, D and Nonhebel, H.M. 2009. Induced tolerance of Sclerotinia sclerotiorum to isothiocynates and toxic volatiles from Brassica species. Plant Pathology. 58: 479-486.

Snapp, S.S., Date, K.U., Kirk, W., O’Neil, K., Kremen, A and G. Bird. 2007. Root, shoot tissues of Brassica juncea and Cereal secale promote potato health. Plant and Soil 294(12):55-72

\section{How to cite this article:}

Yella Goud T., G. Uma Devi, P. Narayan Reddy and Siva Sankar A. 2017. Effect of Volatile Toxins of Brassica Residues on Groundnut Stem and Pod Rot Disease caused by S. rolfsii. Int.J.Curr.Microbiol.App.Sci. 6(11): 5466-5470. doi: https://doi.org/10.20546/ijcmas.2017.611.524 